\title{
Selection and valorization of arbuscular mycorrhizal fungi isolated from phosphate sludge basins in promoting of citrus and carob seedlings
}

\author{
Zakaria BAIZ ${ }^{* 1,2}$, Mohammed ELGUILLI $^{2}$, Khalid AZIM $^{2}$, Jamila DAHMANI ${ }^{1}$, and Younes ABBAS $^{3}$ \\ ${ }^{1}$ Laboratory of Plant, Animal and Agro-industry productions, Ibn Tofaïl University, Kénitra \\ ${ }^{2}$ National Institute of Agricultural Research; Regional Center for Agricultural Research - Agadir, Morocco National \\ ${ }^{3}$ Polyvalent Laboratory, R\&D, Polydisciplinary Faculty, USMS- Béni Mellal
}

\begin{abstract}
Accumulation of phosphate sludge (PS) generated from phosphate treatment process in the open air represent an environment risk and a problem in terms of storage capacities. The use of this by-products in agriculture, is an alternative recovery technique for the phosphate. Moreover, selection of symbionts and their inoculation into the soil whether in the nursery or at field were strongly encouraged. These inoculants were selected not only for their impact on the plant, but also for their ability to persist in the soil at the expense of the residual native microflora. This can be performed to the microorganisms which could occur in the solid sludges deriving the exploitation of phosphates in a pilot site of Khouribga area. In this context, the indigenous mycorrhizal resources have been exploited through better exploration of the local floristic diversity and then a series of mycorrhizal fungi selection and production tests have been made. The mycorrhizal complex was prepared and their effect was tested in Citrus and carob plants growth in the nursery. Two mixtures of PS were carried out: $10 \%$ (S2) and $40 \%$ (S5) for Citrus plants and $20 \%$ (S3) and $40 \%$ (S5) for carob plants. The sandy soil of Maamora forest was used as a control (S1). The results shown three dominant morphotypes were detected: Rhizophagus irregularis, Funnileformis constrictum and Scutellospora calospora. The effect of the PS with the AMF-based inoculum indicate that mycorrhizal inoculation of the substrates by a raw inoculum stimulates the growth of plants specially S2, S5 and S3 for Citrus volkameriana, Carrizo citrange and carob respectively. Based on these results, this combination between PS and mycorrhizal fungi had a great effect on Citrus and carob plant in the nursery.
\end{abstract}

\section{Introduction}

Phosphorus (P) is an essential macronutrient, the most requested by the plant. It plays an important role in many physiological activities such as cell division, photosynthesis and the development of a good root system and the utilization of carbohydrates [1], despite the fact that phosphorus is largely and abundantly distributed in the soil under its inorganic and organic properties, many soils around the world are deficient in $\mathrm{P}$ due to the fact that it is not readily accessible for both plant growth and immobilization metal [2]. In soils, insoluble P compounds can be solubilized by phosphatase enzymes, organic acids and complexing agents produced by plants and microorganisms [3]. Morocco, with its large share of the world's phosphate reserves, is the leading exporter of phosphate and its derivatives. Enrichment process of phosphate ores generate huge amounts of sludge and flotation tailings deposited together (Phosphate sludge) in basins over an area of several dozen hectares [4]. This represents a significant environmental problem in the country.

Additionally, arbuscular mycorrhizal fungi (AMF) are well known to improve plant growth and $\mathrm{P}$ nutrition [5]. Colonization of roots by AMF increases root surface area, improving plant nutrient acquisition, soil structure, and plant protection against environmental stresses [6]. AMF are key components of the soil microbial community, directly influencing the uptake of water and nutrients, such as $\mathrm{P}$. In addition, AMF take up P from soil solution but cannot extract on their own the P of the PR; however, when combined with PR-solubilizing bacteria, AMF can translocate $\mathrm{P}$ from Rock $\mathrm{P}$ into their host plant [7]. The AMF symbiosis also alters the chemical characteristics of plant root exudates, altering associated microbial communities in the rhizosphere [6, 8, 9]. The zone of influence of mycorrhizae in the rhizosphere is known as the mycorrhizosphere [10], and the morphological and physical changes generated by the association of the AMF symbiosis with the roots (which modify the conditions of the surrounding soil and impact the microbial community) are known as the mycorrhizosphere effect $[11,8]$. As a result, mycorrhizas promote plant growth under various abiotic and biotic stress conditions [12, 13, 14, 15].

These symbiotic microorganisms help plants to obtain nutrients which are very often limiting in the soil. By improving the physiology of the plant, especially in conditions of water and nutrient stress, the inoculation technique represents a strong opportunity in dry areas to increase agricultural and forestry production, while improving soil fertility through a non-polluting practice 
[16]. In this study, the aim is select and promote mycorrhizal fungi isolated from phosphate sludge basins in order to choose the better inoculum to be incorporate into a substrate of culture based on solid sludge releases for the growth of Citrus and carob plants.

\section{MATERIALS AND METHODS}

\subsection{Study sites}

This study was conducted in eight sampling points in the solid sludges deriving of the exploitation of phosphates ores in a pilot site of Khouribga area in Beni Mellal Khénifra region of Morocco. The geographical position and physical and chemical soil characteristics of are given in table1 and figure 1.

Table 1. Physicochemical proprieties of phosphate sludge.

\begin{tabular}{|c|c|}
\hline Parameters & Solid Phosphate sludges \\
\hline pH du sol (in water) & 8.22 \\
EC (ms/cm) & 0.35 \\
N Total (\%) & 0.49 \\
Matière organique (\%) & 0.45 \\
P disponible (\%) & 16.3 \\
P Total (\%) & 10.22 \\
K échangeable (\%) & 0.16 \\
Argile (\%) & 28 \\
Calcaire total (\%) & 42 \\
Texture & limon argileux \\
\hline
\end{tabular}

\subsection{Vegetation at the studied sites}

In addition to the taxonomic identity of fungi, habitat information is as important as when selecting isolates for practical use [17]. At pilot site, the most common plant species were: Tamarix sp., Nicotiana glauca, Atriplex halimus, Medicago Arabica and Acacia sp.

\subsection{Sample collection}

The sampling was conducted in Avril 2018. Approximately 3 to $5 \mathrm{~kg}$ of soil around plants roots were collected at site in 8 different points. To obtain a representative sample for the entire site, depth soils of 10 to $70 \mathrm{~cm}$ were taken and homogenized. Additionally, for arbuscular mycorrhizal spore extraction and physicochemical analyses, $3 \mathrm{~kg}$ sub-sample of homogenized soil was taken to the laboratory.

\subsection{Root clearing and staining}

Fine roots were collected (One to $5 \mathrm{~g}$ ) and maintained in a glycerol/ethanol/distilled water (GEE) solution [18]. The ectomycorrhizae was first screened for the possible presence under a stereomicroscope. To reveal fungal structures, roots were cleared in $10 \% \mathrm{KOH}$ and stained with $0.05 \%$ trypan blue in lactophenol [19]. Fragments were cut into $1 \mathrm{~cm}$ of stained roots and crushed on slides in a drop of polyvinyl alcohol-lacto-glycerol (PVLG: 8.33 g polyvinyl alcohol, $50 \mathrm{~mL}$ lactic acid, $5 \mathrm{~mL}$ glycerine and $50 \mathrm{~mL}$ water) [20]. Each slide contains 5 to 10 fragments with 10 replications. As described by Trouvelot and al. [21], the fragments were observed under a microscope (10× and $40 \times$ magnification) to estimate the extent of arbuscular mycorrhizal infection. The procedure implicate scoring the proportion of cortex colonized by the endomycorrhizal symbiont as follows: 0 : no fungal in fection, 1: trace of fungal infection, 2 : less than $10 \%$ of

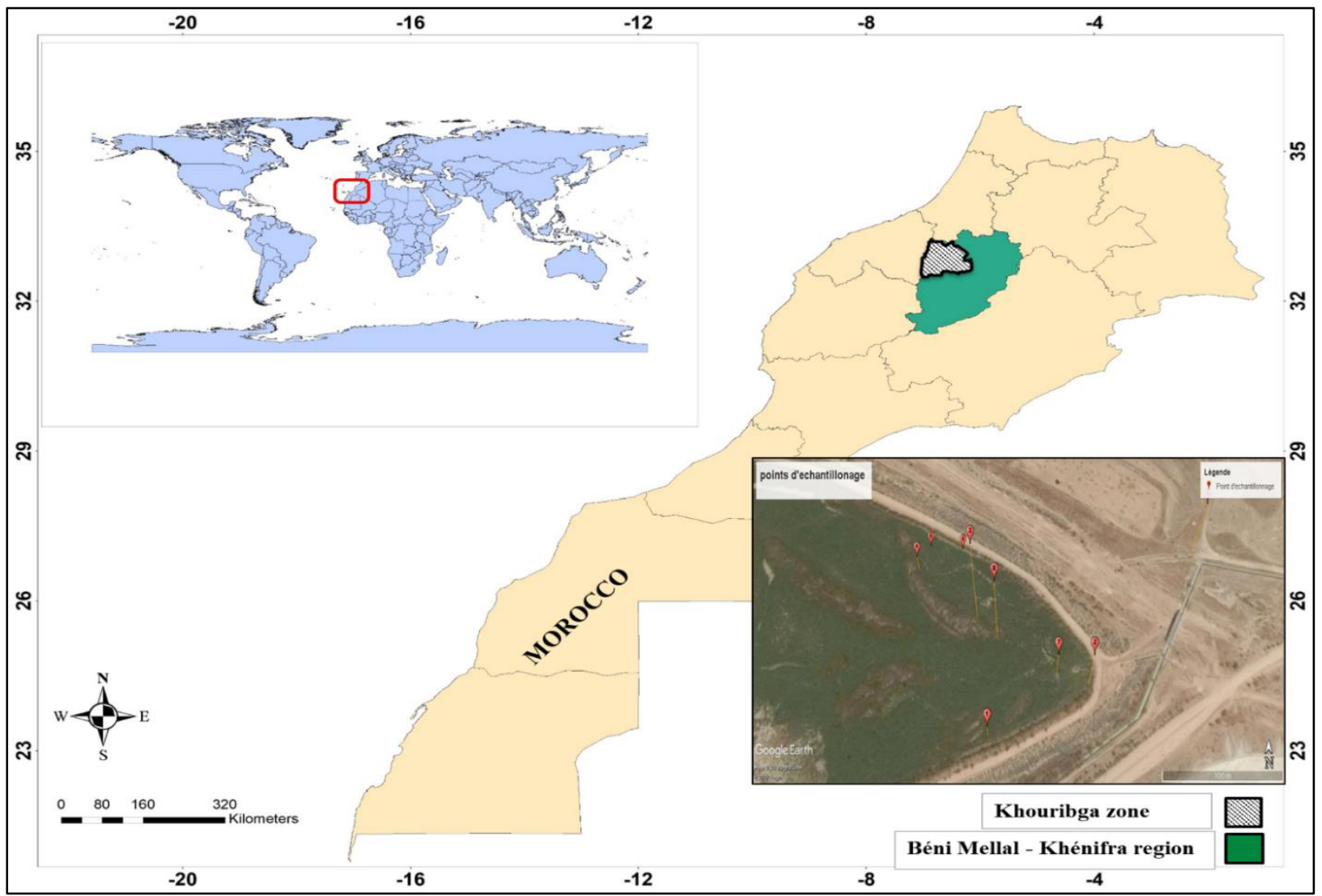

Fig. 1. Geographic localization of sampling. 
fungal infection, 3: fungal infection ranging from 11 to $50 \%$, 4: fungal infection ranging from 51 to $90 \%$ and 5 : fungal infection over $90 \%$. These scores were used to calculate mycorrhizal frequency (F \%):

$$
F=100(N-n 0) / N
$$

Where; $N$ is the total number of observed fragments and $n 0$ is the number of fragments without mycorrhizae.

\subsection{Extraction of AM fungus spores}

The extraction of Glomalean spores from the soil was determined by Gerdemann and Nicolson [22] method. 100 grams of soil were sieved on 500 to $50 \mu \mathrm{m}$ mesh sieves and centrifuged in a water sucrose solution $(50 \% \mathrm{w} / \mathrm{v})$ for $10 \mathrm{~min}$ at $1500 \mathrm{rpm}$. Spores were counted and grouped according to their morphological characteristics under a stereomicroscope. The relative abundance and richness of each fungal type were calculated per $100 \mathrm{~g}$ of dry soil.

\subsection{Spore identification}

Morphological characters: colour and spore size were assessed in water under a stereomicroscope. Spores were observed under a microscope to evaluate wall structures and other specific attributes on permanent slides prepared according to Azcon-Aguilar [23].

Morphological features, e.g. colour, size, wall structure and hyphal attachment are the main parameters for spore identification [24, 25]. Morphotypes were classified to the genus level and to the species level when possible.

\subsection{Mycorrhizal Infectious Potential (MPN)}

The mycorrhizal potential of rhizosphere soil samples from different plant species was tested using the Most Probable Number (MPN) technique [26].

\subsection{Preparation of the inoculum (mycorrhizal complex)}

The selected AM fungi were then propagated on the roots of barley plants (Hordeum vulgare L.) with 50 spores of each morphotype against the root system of the mycotrophic plant [27]. The substrate was used is a mixture of sand and sterile sludge, respectively in the ratio 3: 1. After 2 months of cultivation, mycorrhizal barley roots were evaluated for their mycorrhizal rate. Then the barley seedlings were desiccated and the dry substrate was completely collected and put in sachets to serve as an inoculum for Citrus and carob plants in the nursery.

\subsection{Greenhouse experiment}

Mixtures based on the solid phosphates mud and the soil of the Maamora forest were made according to the concentrations which allowed better growth of the plants: mixture S5 (40\% of the phosphate mud $+60 \%$ of Maamora soil), S2 (10\% of phosphate sludge $+90 \%$ Maamora soil) for Citrus and S3 (20\% of phosphate sludge $+80 \%$ Maamora soil), S2 $(10 \%$ of phosphate sludge $+90 \%$ Maamora soil) for the carob plants.

The Citrus rootstocks (Carrizo citrange and Citrus volkameriana) and carob plants were transplanted into 2 $\mathrm{kg}$ pots containing the various mixtures with a $10 \mathrm{~g} / \mathrm{kg}$ strip of mycorrhizal inoculum (mycorrhizal complex) based on selected AMF and which have been propagated on the roots of barley plants (Hordeum vulgare L.) with 50 spores of each morphotype against the root system of the mycotrophic plant [27] in a greenhouse according to a block experiment full random. The plants were watered every second day individually with the same quantity and treated by pesticides against disease fortnightly in the growth room (Greenhouse).

\subsection{Measured parameters}

Plant height, trunk diameter and leaf chlorophyll content (SPAD values) were assessed. The leaf chlorophyll content was determined using a portable chlorophyll meter (SPAD-502, Minolta Co. Ltd., Osaka, Japan). The relative growth was calculated in percentage for each parameter:

$$
R G \%=[(S t-S 0) / S 0] \times 100
$$

Where; $R G$ the relative growth, $\mathbf{S 0}$ is the initial size and $\mathbf{S t}$ is the final size.

\subsection{Statistical analysis method}

Data were analyzed by variance and covariance analysis. Each data representing the average of three replicates. Then the data belonging to the same group are considered not different with the risk equal to $5 \%$. The statistical treatment of the results is carried out using a SPSS Statistics 23 Software.

\section{RESULTS}

\subsection{Natural mycorrhizae}

In all samples, the organisation of mycorrhizae was the same. Microscopic observations of stained roots showed that Nicotiana glauca and Tamarix sp. formed abundant endomycorrhizae. In some cases, the frequency and intensity of mycorrhizal infection reached $100 \%$ for Nicotiana glauca and Tamarix sp. and 32\% for acacia $s p$. (Tab. 2). Different endomycorrhizal structures were observed, including hyphal coils that seemed to ramify straight along the root cortex (Fig. 3) and oval vesicules were present between the cortex cells.

\subsection{Diversity of AMF spores}

The number of spore morphotypes detected at each site, according to shape, colour and size. All spores belonged to the Glomineae order represented by the Glomaceae and Acaulosporaceae families (Fig. 3). Morpho-anatomical analysis of the different species of these fungi revealed the presence of 3 dominant morphotypes: Rhizophagus intraradices (Yellow-brown, elliptical with irregularities and $90 \mu \mathrm{m}$ diam), Funnileformis constrictum (Brown, 60 $\mu \mathrm{m}$ diam) and Scutellospora calospora (Formed terminally on a bulbous subtending hypha; pastel yellow to dark orange, $260 \mu \mathrm{m}$ diam).

\subsection{Relative abundance of common AMF species}

The results of this selection made it possible to realize that the propagules harvested under Nicotiana glauca and Tamarix sp. (Respectively 225 and 110 propagules / 100g of soil) are significantly more efficient than those of other plants (Fig. 4). So our study was focused on the rhizosphere of these two plants in order to multiply and mass produce these mycorrhizal propagules. 
Table 2. Number of spores per $100 \mathrm{~g}$ of rhizospheric soil under N. glauca and Tamarix sp.

\begin{tabular}{|l|c|c|}
\hline \multicolumn{1}{|c|}{ Species } & $\begin{array}{c}\text { Species Average } \\
\text { number of spores per } \\
100 \mathrm{~g} \text { of soil }\end{array}$ & $\mathrm{F} \mathrm{( \% )}$ \\
\hline Nicotiana glauca & $94 \pm 2 \mathrm{a}$ & 100 \\
\hline Tamarix sp. & $91 \pm 1 \mathrm{a}$ & 100 \\
\hline Medicago Arabica & $25 \pm 1 \mathrm{~b}$ & 28 \\
\hline Acacia sp. & $35 \pm 2 \mathrm{~b}$ & 32 \\
\hline
\end{tabular}

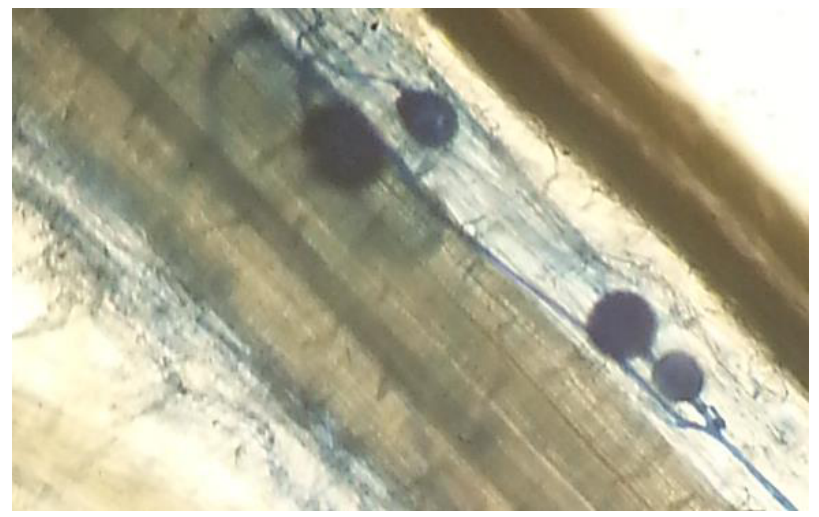

Fig. 2. Mycorrhizal mycotrophic of Nicotiana glauca plant root (Gross 40x).

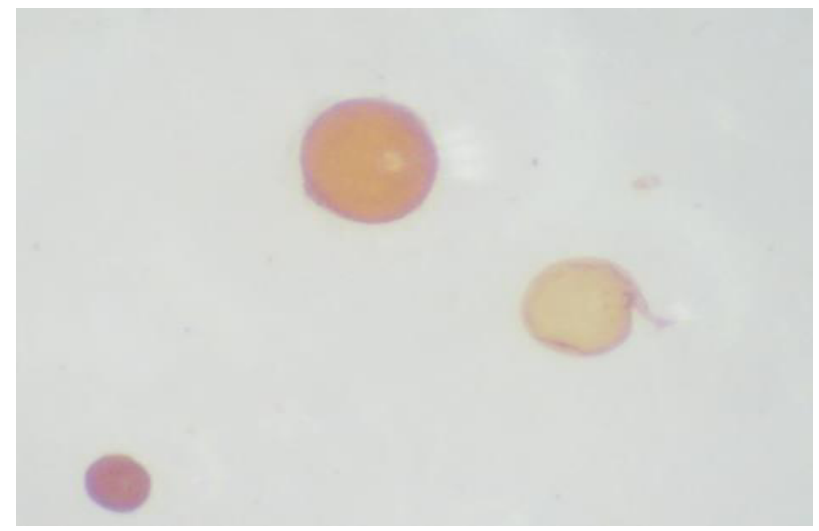

Fig. 3. Spores of Rhizophagus intraradices in mixture with Funnileformis constrictum and Scutellospora calospora (Gross 40x).

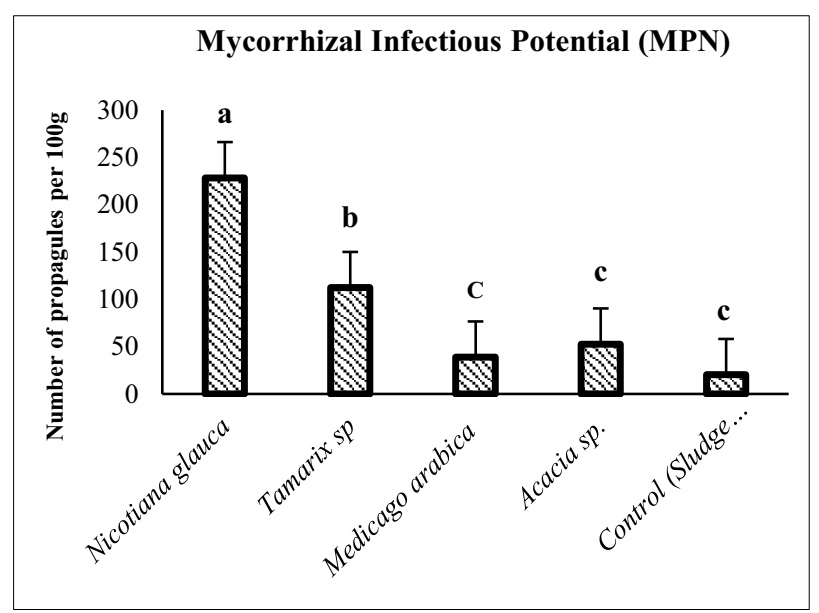

Fig. 4. Mycorrhizal Infectious Potential of the various rhizospheric soils studied.

\subsection{Effect of mycorrhizal inoculum on the growth of Citrus and carob seedling}

The effect of raw mycorrhizal inoculum on the growth of Citrus and carob seedling was determined. The relative height growth of the Citrus volkameriana plants indicates that the best growth was significantly observed in the S2 mixture with $10 \%$ of the phosphate sludge and mycorrhizal inoculum (Table 3).

Additionally, no significant difference was noted for the growth in diameter and chlorophyll index despite the superior growth in the biomass of the plants of the S2 mixture (Table 3).

On the other hand, for Carrizo citrange plants, the highest height growth was observed in the S5 mixture and no difference was obtained for the relative growth in diameter and in chlorophyll index SPAD (Table 3). This difference was noted significantly in the dry weight of shoots and roots. Otherwise, the relative growth and biomass of the higher plants were noticed significantly in mix S3 for the carob plants (Table 3).

The estimation of the progression of the air under the curve was made using the trapezoidal method. For Citrus volkameriana plants, the highest AUGPC was obtained in the S2 mixture although no difference was observed (Fig. 5). In addition, AUGPC is slightly higher in the S5 mix for Carrizo citrange plants and the significant difference was observed in the SPAD chlorophyll index (Fig. 6). For the carob plants, the AUGPC height is significantly greater in the S2 mixture compared to the control mixture. Otherwise, no difference was noticed for the other growth parameters of these plants (Fig. 7).

\section{DISCUSSION}

Experimentation has shown that the solid phosphate sludge, used here as a culture substrate, contains AMF propagules capable of associating with the roots of the plants studied. This soil therefore contains one or more strains of AMF with 3 dominant morphotypes: Rhizophagus intraradices, Funneliformis constrictum and Scutellospora calospora.

The results of the effect of the phosphate sludge with the AMF-based inoculum indicate that mycorrhizal inoculation of the substrates by a raw inoculum stimulates the growth of plants in the nursery. The growth parameters of the plants of Citrus volkameriana and carob plants were greater in the S2 mixture with $10 \%$ of the phosphate sludge. Moreover, for the Carrizo citrange plants the highest growths were observed in the S5 mixture with $40 \%$ of the phosphate sludge. The effect of mycorrhization on plant height has been shown in various species in nursery plants [28]. Aroca [29] reported that Rhizophagus Intraradices significantly improved the expression of plant genes encoding intrinsic plasma membrane proteins (PIP) in roots and resulted in a remarkable increase in shoot dry weight under drought conditions. Additionally, two functional aquaporins of $R$. intraradices were shown to be responsible for a significant increase in the relative water content of the roots of maize plants [30]. As P mobilization from soil resources was strongly correlated with plant $\mathrm{P}$ contents, this effect is likely to be indirectly caused by AMF media- 
Table 3. Effect of gross mycorrhizal inoculum from solid phosphate sludge on the growth of Citrus and carob plants in the nursery.

\begin{tabular}{|c|c|c|c|c|c|c|}
\hline Species & Mixtures & $\begin{array}{c}\text { Relative growth } \\
\text { in height }(\%)\end{array}$ & $\begin{array}{c}\text { Relative } \\
\text { growth in } \\
\text { diameter }(\%)\end{array}$ & $\begin{array}{l}\text { Chlorophyll } \\
\text { index (SPAD) }\end{array}$ & $\begin{array}{l}\text { Dry weight } \\
\text { of shoot (g) }\end{array}$ & $\begin{array}{l}\text { Dry weight } \\
\text { of root (g) }\end{array}$ \\
\hline $\begin{array}{c}\text { Citrus } \\
\text { volkameriana }\end{array}$ & $\begin{array}{l}\mathrm{S} 1 \\
\mathrm{~S} 2 \\
\mathrm{~S} 5\end{array}$ & $\begin{array}{l}68.25 \mathrm{~b} \\
82.53 \mathrm{a} \\
39.93 \mathrm{c}\end{array}$ & $\begin{array}{l}124.74 \mathrm{a} \\
135.55 \mathrm{a} \\
120.40 \mathrm{a} \\
\end{array}$ & $\begin{array}{l}44.53 \mathrm{a} \\
50.31 \mathrm{a} \\
39.86 \mathrm{a} \\
\end{array}$ & $\begin{array}{l}.03 \mathrm{~b} \\
5.42 \mathrm{a} \\
1.03 \mathrm{c} \\
\end{array}$ & $\begin{array}{l}0.98 \mathrm{~b} \\
4.63 \mathrm{a} \\
0.76 \mathrm{~b}\end{array}$ \\
\hline $\begin{array}{l}\text { Carrizo } \\
\text { citrange }\end{array}$ & $\begin{array}{l}\mathrm{S} 1 \\
\mathrm{~S} 2 \\
\mathrm{~S} 5\end{array}$ & $\begin{array}{c}135.18 \mathrm{a} \\
40.74 \mathrm{~b} \\
140.74 \mathrm{a}\end{array}$ & $\begin{array}{l}137.77 \mathrm{a} \\
134.34 \mathrm{a} \\
133.63 \mathrm{a}\end{array}$ & $\begin{array}{l}38.13 \mathrm{a} \\
22.9 \mathrm{~b} \\
41.3 \mathrm{a}\end{array}$ & $\begin{array}{l}3.25 \mathrm{ab} \\
2.11 \mathrm{~b} \\
4.39 \mathrm{a}\end{array}$ & $\begin{array}{l}4.73 \mathrm{~b} \\
1.05 \mathrm{c} \\
6.24 \mathrm{a} \\
\end{array}$ \\
\hline Carob & $\begin{array}{l}\text { S1 } \\
\text { S3 } \\
\text { S5 }\end{array}$ & $\begin{array}{l}168.88 \mathrm{c} \\
364.66 \mathrm{a} \\
208.88 \mathrm{~b}\end{array}$ & $\begin{array}{l}112.42 \mathrm{~b} \\
146.76 \mathrm{a} \\
145.65 \mathrm{a}\end{array}$ & $\begin{array}{l}39.22 \mathrm{a} \\
37.52 \mathrm{a} \\
35.95 \mathrm{a}\end{array}$ & $\begin{array}{l}4.66 \mathrm{~b} \\
6.41 \mathrm{a} \\
1.36 \mathrm{c}\end{array}$ & $\begin{array}{l}2.87 \mathrm{~b} \\
3.40 \mathrm{a} \\
0.87 \mathrm{c}\end{array}$ \\
\hline
\end{tabular}

The means followed by the same letter in the same column do not differ significantly from each other according to the Tukey test at $p$ $<0.05$.

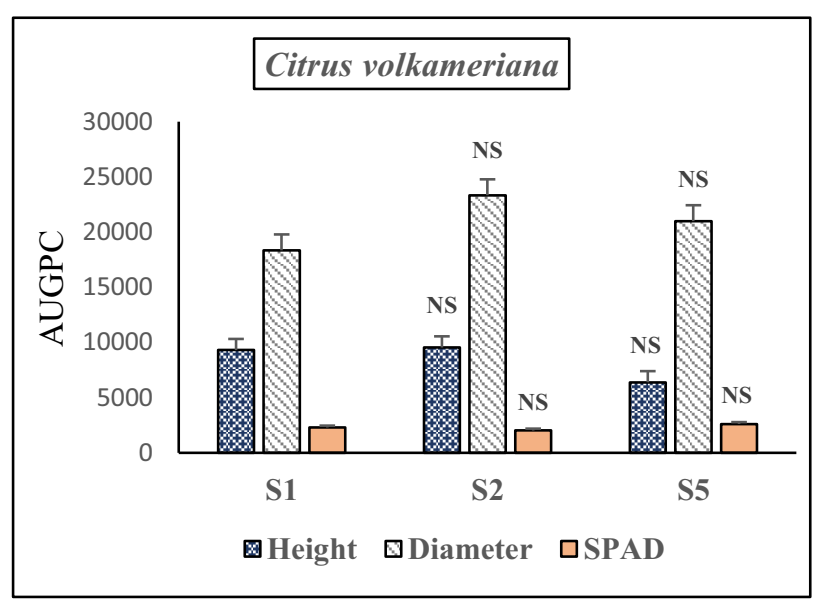

Fig. 5. Estimates of AUGPC of various parameters measured for Citrus volkameriana plants; statistically significant differences are indicated as $P<0.05$ from the control mixture.

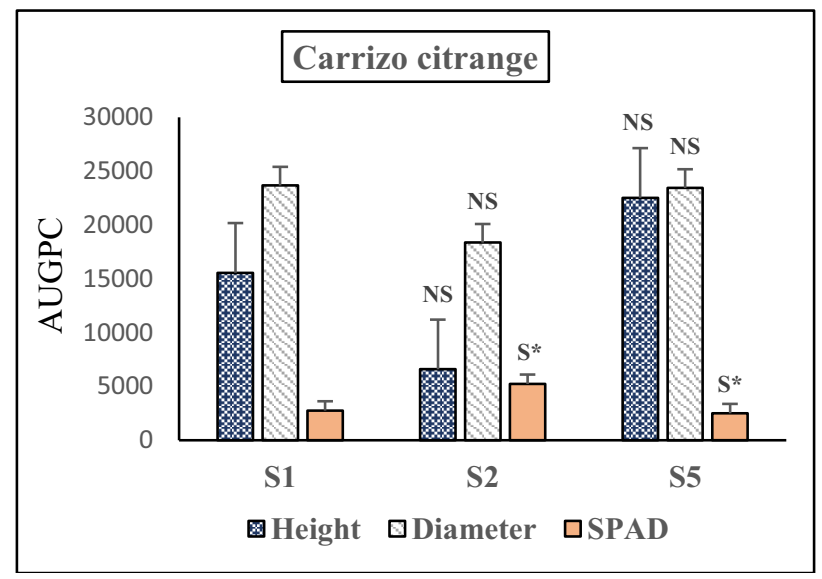

Fig. 6. Estimates of AUGPC of various parameters measured for Carrizo citrange plants; statistically significant differences are indicated as $P<0.05$ from the control mixture.

ted improvements in plant nutrition [31]. The amendments of the phosphate sludge add significant concentrations of $\mathrm{P}$ not available. According to Hakkou [4], solid phosphate sludge is quite rich in total P (14 to $16 \%)$. We therefore suggest that inoculation of substrates with AMF increases the availability of $\mathrm{P}$ in mixtures in order to promote plant growth.

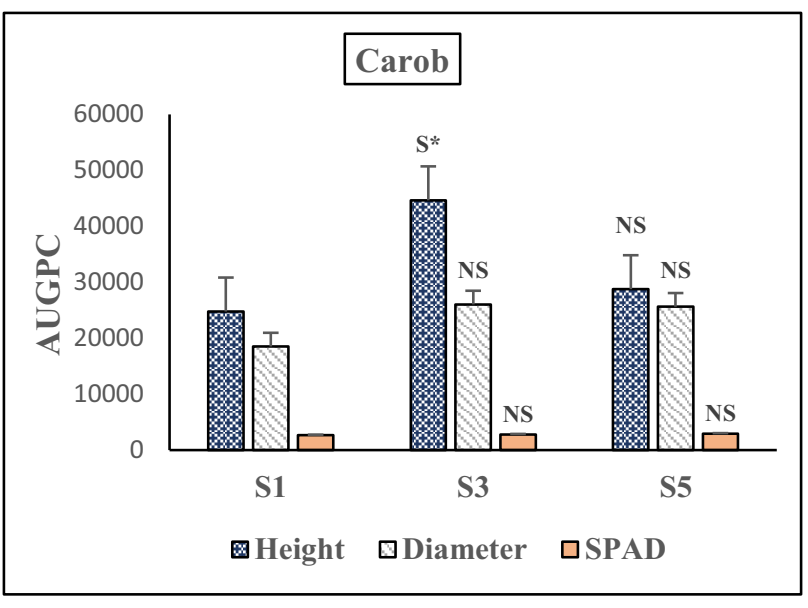

Fig. 7. Estimates of AUGPC of various parameters measured for carob plants; statistically significant differences are indicated as $P<0.05$ from the control mixture.

Furthermore, and although it is believed that AMF do not have saprotrophic abilities [32], it has been shown to use nutrients derived from organic matter [33, 34] and may also indirectly improve mineralization of organic matter [35, 36, 37]. Some studies also suggest direct uptake of organic $\mathrm{N}$ compounds from soil [38, 39, 40].

Citrus plants are necessarily dependent on mycorrhizal colonization $[41,42]$ and so far this dependence has been shown to be mainly related to the nutrition of $\mathrm{P}$. Phosphorus may be a limiting factor major for plant growth because it is extremely immobile in soils. Large amounts of the soluble form of $P$ in fertilizers can be immediately converted by reaction with soil calcium to insoluble phosphate, which is not available to plants [43]. Mycorrhizal inoculation can influence the $\mathrm{pH}$ of the rhizosphere, which can increase the absorption of $\mathrm{P}$ [44, 45]. Otherwise, mycorrhizal symbioses can increase the spatial availability of $\mathrm{P}$, extending the nutrient uptake surface through the formation of mycorrhizal hyphae. The distribution of hyphae in areas of soil where the roots are absent and the greater contact of hyphae with the soil largely contribute to the increase in nutrient uptake [46]. Phosphorus uptake per unit root length (influx) has been shown to be faster in mycorrhizal plants than in nonmycorrhizal plants [47], resulting in higher concentrations 
of $\mathrm{P}$ in the plants, shoots and roots, and therefore, improving plant growth.

The difference between Citrus rootstocks can be related to the nutrient requirements of the plants and the physicochemical parameters of each mixture as mentioned in the previous chapters. In general, the positive effect of AMF has not always been linked to the high inputs of the phosphate sludge, other factors namely the $\mathrm{pH}$ and the organic content of the mixtures should be taken into account. This is evident in Citrus volkameriana plants which prefer the S2 mixture with $10 \%$ sludge and Carrizo citrange plants which prefer the S5 mixture with $40 \%$ phosphate sludge.

As previously demonstrated by Ouahmane [48] and Manaut [49], a strong mycorrhizal dependence of carob plants was observed under our conditions. Ouahmane [48] also showed that the diversity of the AMF was recorded the dominance of Glomeraceae (Rhizophagus intraradices / irregularis) in the roots of carob tree. It has been shown that AMF stimulate plant growth and nutrient uptake [50]. This could explain the high growth which was observed in the plans of the S3 mixture (20\% sludge) with the inoculum containing the mycorrhizal spores including Rhizophagus intraradices.

\section{Conclusion}

In conclusion, the phosphate sludge resulting from the different treatments and which is dumped in nature can be reused if we think back to nature based solutions. Indeed, better management of the microbial potential that sets in following the different plant / microorganism combinations is an extensive alternative which has shown its effectiveness in this study. The solid sludge of phosphates, despite their physicochemical characteristics, harbor, after the installation of a certain number of plants, one or more strains of AMF, the study of which has shown the dominance of 3 morphotypes which have been isolated and identified: Rhizophagus intraradices, Funneliformis constrictum and Scutellospora calospora. The mycorrhizogenic potential of the rhizosphere of two species of target plants (Nicotiana glauca and Tamarix $s p$.) supports our suggestion and suggests that certainly the introduction at the level of these sites of plants with greater mycorrhizogenic power can only be beneficial either for its rehabilitation or the reuse of this sludge. Also, it is useful to remember that, despite the time allocated to the cultivation of the plants in the nursery, the results of inoculation with the mycorrhizal complex isolated from this sludge showed its effectiveness at least in terms of the relative growth of the Citrus or carob plants. It is sufficient to optimize the choice of an effective growing medium based on the appropriate mixtures for each type of culture.

\section{Acknowledgements}

The Authors would like to acknowledge the support through the R\&D Initiative - Appel à projets autour des phosphates APPHOS - sponsored by OCP (OCP Foundation, R\&D OCP, Mohammed VI Polytechnic University, National Center of
Scientific and technical Research CNRST, Ministry of Higher Education, Scientific Research and Professional Training of Morocco MESRSFC) under the project entitled "Valorisation des boues solides des phosphates en arboriculture fruitière et foresterie"; project ID: [BIO-ELG-01/2017].

\section{References}

1. S. Sharma, V. Kumar, R.B. Tripathi, (2011). Isolation of phosphate solubilizing microorganism (PSMs) from soil. J. Mico. Biot. Res. 1, 90.

2. J.H. Park, N.B. Bolana, M. Megharaja, R. Naidua, (2011). Isolation of phosphate solubilizing bacteria and their potential for lead immobilization in soil. J. Hazard Mater. 185, 829. https://doi.org/10.1016/j.jhazmat.2010.09.095

3. B. Drigo, S. Donn, (2017). Trading carbon between arbuscular mycorrhizal fungi and their hyphae-associated microbes. In: Mycorrhizal Mediation of Soil, vol 22. pp. 395. https://doi.org/10.1016/B978-0-12-8043127.00022-X

4. R. Hakkou, M. Benzaazoua, \& B. Bussière, (2016). Valorization of Phosphate Waste Rocks and Sludge from the Moroccan Phosphate Mines: Challenges and Perspectives. Procedia Engineering, 138, 110-118. https://doi.org/https://doi.org/10.1016/j.proen g.2016.02.068.

5. A. Roy-Bolduc, M. Hijri (2010). The use of mycorrhizae to enhance phosphorus uptake: a way out the phosphorus crisis. Biofertilizers \& Biopesticides 2:104. DOI: $10.4172 / 2155-$ 6202.1000104

6. J. M. Barea, M. Toro, M. O. Orozco, E. Campos \& R. Azcón, (2002). The application of isotopic (32P and $15 \mathrm{~N}$ ) dilution techniques to evaluate the interactive effect of phosphate-solubilizing rhizobacteria, mycorrhizal fungi and Rhizobium to improve the agronomic efficiency of rock phosphate for legume crops. Nutrient Cycling in Agroecosystems, 63(1), 35-42. https://doi.org/10.1023/A:1020589732436

7. S. Taktek, M. Trépanier, P. Magallón-Servín, M. St-Arnaud, Y. Piché, JA. Fortin, H. Antoun (2015) Trapping of phosphate solubilizing bacteria on hyphae of the arbuscular mycorrhizal fungus Rhizophagus irregularis DAOM 197198. Soil Biol Biochem 90:1-9. https://doi.org/10.1016/j.soilbio.2015.07.016

8. M. Bansal, KG. Mukerji (1994). Positive correlation between VAMinduced changes in root exudation and mycorrhizosphere mycoflora. Mycorrhiza 5:39-44. 
9. D. L. Jones, A. Hodge, Y. Kuzyakov (2004). Plant and mycorrhizal regulation of rhizodeposition. New Phytol 163:459-480. https://doi.org/10.1111/j.14698137.2004.01130.x

10. E. T. Oswald, HA. Ferchau (1968). Bacterial associations of coniferous mycorrhizae. Plant. S. 28:187-192.

https://doi.org/10.1007/BF01349190

11. K. Mansfeld-Giese, J. Larsen, L. Bodker (2002). Bacterial populations associated with mycelium of the arbuscularmycorrhizal fungus Glomus intraradices. FEMS Microbiol Ecol 41:133- 140. https://doi.org/10.1111/j.15746941.2002.tb00974.x

12. J. D. He, T. Dong, H.H. Wu, Y.N. Zou, Q.S. Wu, K. Kuča (2019): Myᄀcorrhizas induce diverse responses of root TIP aquaporin gene expression to drought stress in trifoliate orange. Scientia Horti-culturae, 243: 64-69. https://doi.org/10.1016/j.scienta.2018.08.010

13. Q. S. Wu, J.D. He, A.K. Srivastava, F. Zhang, Y.N. Zou (2019): Development of propagation technique of indigenous AMF and their inoculation response in Citrus. Indian J. of Agri. Sci, 89: 1190-1194.

14. F. Zhang, P. Wang, Y.N. Zou, Q.S. Wu, K. Kuča (2019): Effects of mycorrhizal fungi on root-hair growth and hormone levels of taproot and lateral roots in trifoliate orange under drought stress. Archives of Agr. and S. Sci, 65: 1316-1330. https://doi.org/10.1080/03650340.2018.15637 $\underline{80}$

15. F. Zhang, Y.N .Zou, Q.S. Wu, K .Kuča (2020): Arbuscular mycor $\neg$ rhizas modulate root polyamine metabolism to enhance drought tolerance of trifoliate orange. Environmental and Experimental Botany, 171: 103926. https://doi.org/10.1016/j.envexpbot.2019.1039 26

16. Duponnois et A.D. Robin (2012). LA GRANDE MURAILLE VERTE : Capitalisation des recherches et valorisation des savoirs locaux. DOI : $10.4000 /$ books.irdeditions.3247.

17. M. Brundrett, N. Bougher, B. Dell, T. Grove, N. Malajczuk, Working with mycorrhizas in forestry and agriculture, Australian Centre for International Agricultural Research (ACIAR), monograph 32, Canberra, Australia, 1996, 374 p. DOI: $10.13140 / 2.1 .4880 .5444$

18. M. Ducousso. Importance des symbioses racinaires pour l'utilisation des acacias en Afrique de l'Ouest. Thèse, Université Claude Bernard, Lyon I (CIRAD-ISRA), Nogent sur Marne, France et Dakar, Sénégal, 1991, 205 p.

19. J. M. Phillips, D.S. Hayman, Improved procedure for clearing roots and staining parasitic and vesicular-arbuscular fungi for rapid assessment of infection, Trans. Brit. Mycol. Soc. 55 (1970) 158-160. https://doi.org/10.1016/S0007$1536(70) 80110-3$

20. R. E. Koske, B. Tessier, A convenient permanent slide mounting medium, Mycological Society of America Newsletter 34 (1983) 59.

21. A. Trouvelot, J. Kouch, V. Gianinazzi-Pearson, Les mycorhizes, physiologie et génétique, INRA, 1986, pp. 217-221.

22. J. W. Gerdemann., T.H. Nicolson, Spores of mycorrhizal Endogone species extracted from soil by wet sieving and decanting, Trans. Brit. Mycol. Soc. $46 \quad$ (1963) 235. https://doi.org/10.1016/S0007-1536(63)80079$\underline{0}$

23. C. Azcón-Aguilar, J. Palenzuela, A. Roldán, S. Bautista, R. Vallejo, J.M. Barea, Analysis of the mycorrhizal potential in the rhizosphere of representative plant species from desertification-threatened Mediterranean shrublands, Appl. Soil Ecol. 22 (2003) 29-37. https://doi.org/10.1016/S0929-1393(02)00107$\underline{5}$

24. International Culture Collection of (Vesicular) Arbuscular Mycorrhizae (INVAM) (1997), http://www.invam.caf.wvu.edu/

25. J. B. Morton, G.L. Benny, Revised classification of arbuscular mycorrhizal fungi (Zygomycetes): a new order, Glomales, two new suborders, Glomineae and Gigasporineae, and two new families, Acaulosporaceae and Gigasporaceae, with an emendation of Glomaceae, Mycotaxon 37 (1990) 471-491.

26. E. Sieverding, VAM management in tropical agrosystems, Deutsche Gesellschaft fur Technische Zusammenarbeit (GTZ), Eschborn; Germany, 1991.

27. I. Weissenhorn, C. Leyval, G. Belgy, et al. Arbuscular mycorrhizal contribution to heavy metal uptake by maize (Zea mays L.) in pot culture with contaminated soil. Myco. 5, 245251 https://doi.org/10.1007/BF00204957.

(1995).

28. M. L. Ruiz, D. Carvajal- Sanchez \& C. A. Espinosa (2016). Efecto de las micorrizas y otros biofertilizantes en papaya, guayaba y aguacate en suelos ferraliticos rojos y pardos mullidos carbonatados. Rev. Agri. Tropical Vol 2 NO. 2:21-30.

29. R. Aroca, M. M. Alguacil, P. Vernieri, J. M. RuizLozano (2008). Plant responses to drought stress and exogenous ABA application are modulated differently by mycorrhization in tomato and an ABAdeficient mutant (Sitiens). Microb Ecol 56:704-719. https://doi.org/10.1007/s00248-008-9390-y 
30. T. Li, Y. J. Hu, Z. P. Hao, H. Li, Y. S. Wang, B. D. Chen (2013). First cloning and characterization of two functional aquaporin genes from an arbuscular mycorrhizal fungus Glomus intraradices. New Phytol 197:617-630. https://doi.org/10.1111/nph.12011

31. S. Bender, C. Franz, G.A. Marcel, V. D. Heijden (2015). Mycorrhizal effects on nutrient cycling, nutrient leaching and $\mathrm{N} 2 \mathrm{O}$ production in experimental grassland. Soil Biology \& Biochemistry $\quad 80 \quad$ (2015) 283e292. http://dx.doi.org/10.1016/i.soilbio.2014.10.016.

32. S. E. Smith, F. A. Smith, 2011. Roles of arbuscular mycorrhizas in plant nutrition and growth: new paradigms from cellular to ecosystem scales. Annual Review of Plant Biology 62, 227e250. https://doi.org/10.1146/annurev-arplant042110-103846

33. G. Feng, , Y. C. Song, , X. L .Li, , P. Christie, 2003. Contribution of arbuscular mycorrhizal fungi to utilization of organic sources of phosphorus by red clover in a calcareous soil. Applied Soil Ecology 22, $139 \mathrm{e} 148$. https://doi.org/10.1016/S0929-1393(02)00133$\underline{6}$

34. A. Hodge, A. H. Fitter, 2010. Substantial nitrogen acquisition by arbuscular mycorrhizal fungi from organic material has implications for $\mathrm{N}$ cycling. Proceedings of the National Academy of Sciences of the United States of America 107, $13754 \mathrm{e} 13759$.

https://doi.org/10.1073/pnas.1005874107

35. A. Hodge (2001). Arbuscular mycorrhizal fungi influence decomposition of, but not plant nutrient capture from, glycine patches in soil. New Phytologist 151: 725- 734.

36. A. Atul-Nayyar, C. Hamel, K. Hanson, J. Germida, 2009. The arbuscular mycorrhizal symbiosis links $\mathrm{N}$ mineralization to plant demand. Mycorrhiza 19, 239e246. https://doi.org/10.1007/s00572-008-0215-0

37. L. Cheng, F. L. Booker, C. Tu, K. O. Burkey, , L. Zhou, H. D. Shew, T. W. Rufty, S. Hu, 2012. Arbuscular mycorrhizal fungi increase organic carbon decomposition under elevated $\mathrm{CO} 2$. Science 337, 1084e1087. https://doi.org/10.1126/science.1224304

38. H. J. Hawkins, A. Johansen, E. George, 2000. Uptake and transport of organic and inorganic nitrogen by arbuscular mycorrhizal fungi. Plant and Soil 226, 275e285. https://doi.org/10.1023/A:1026500810385

39. M. D. Whiteside, M. O. Garcia, K. K. Treseder, 2012. Amino acid uptake in arbuscular mycorrhizal plants. PloS One 7. https://doi.org/10.1371/journal.pone.0047643

40. M. D. Whiteside, K. K. Treseder, P. R. Atsatt, 2009. The brighter side of soils: quantum dots track organic nitrogen through fungi and plants. Ecology 90, 100e108. https://doi.org/10.1890/07-2115.1

41. J. H. Graham, D. M. Eissenstat, 1994. Host genotype and the formation of and function of VA mycorrhizae. Plant Soil 159, 179-185. https://doi.org/10.1007/BF00000107

42. K. Vinayak, D. J. Bagyaraj, 1990. Vesiculararbuscular mycorrhizae screened for troyer citrange. Biol. Fertil. Soils 9, 311-314.

43. A. Zaidi, M. S. Khan, M. Ahemad, M. Oves (2009). Plant growth promotion by phosphate solubilizing bacteria. Acta Microbiol. Immunol. Hung. 56, 263-284. https://doi.org/10.1556/amicr.56.2009.3.6

44. J. Ruan, F. Zhang, M. H. Wong (2001). Effect of nitrogen form and phosphorus source on the growth, nutrient uptake and rhizosphere soil property of Camellia sinensis L. Plant Soil 223, 63-71.

https://doi.org/10.1023/A:1004882001803

45. Q. Yao, X. L. Li, G. Feng, P. Christie (2001). Mobilization of sparingly soluble inorganic phosphates by the external mycelium of an arbuscular mycorrhizal fungus. Plant Soil 230, 279-285.

https://doi.org/10.1023/A:1010367501363

46. S. Joubert, E. Archer (2000). The Influence of Mycorrhiza on Vines Wynboer. A Technical Guide for Wine Producers 130. pp. 86-88.

47. F. A. Smith, S. E. Smith, B. J. St John, D. J. D. Nicholas (1986). Inflow of $N$ and $P$ into roots of mycorrhizal and non-mycorrhizal onions. In: Gianinazzi-Pearson, V., Gianinazzi, S. (Eds.), Physiological and Genetical Aspects of Mycorrhizae. INRA, Paris, France, pp. 371-375.

48. L. Ouahmane, I. Ndoye, A. Morino, A. Ferradous, Y. Sfairi, M. Al Faddy, M. Abourouh (2012). Inoculation of Ceratonia siliqua L. with native arbuscular mycorrhizal fungi mixture improves seedling establishment under greenhouse conditions. Afr. J. Biotechnol. 11, 16422-16426. DOI: $10.5897 / A J B 12.1163$

49. N. Manaut, H. Sanguin, L. Ouahmane, M. Bressan, J. Thioulouse, E. Baudoin, A. Galiana, M. Hafidi, Y. Prin, R. Duponnois, 2015. Potentialities of ecological engineering strategy based on native arbuscular mycorrhizal community for improving afforestation programs with carob trees in degraded environments. Ecological Engineering 79 (2015) 113-119. 
http://dx.doi.org/10.1016/j.ecoleng.2015.03.00 $\underline{7}$

50. S. E. Smith, D. J. Read, 2008. Mycorrhizal Symbiosis, third ed. Academic press, San Diego, CA, USA. 